\title{
Evaluation of Milk Urea Nitrogen as a Diagnostic of Protein Feeding
}

\author{
J. Nousiainen, ${ }^{1}$ K. J. Shingfield, ${ }^{2,3}$ and P. Huhtanen ${ }^{2}$ \\ ${ }^{1}$ Valio Ltd, Farm Services, P.O. Box 10, FIN-00039 Valio, Finland \\ ${ }^{2}$ MTT Agrifood Research Finland, Animal Production Research, \\ FIN-31600 Jokioinen, Finland \\ ${ }^{3}$ School of Food Biosciences, The University of Reading, \\ PO Box 226, Reading, RG6 6AP, UK
}

\begin{abstract}
An evaluation of milk urea nitrogen (MUN) as a diagnostic of protein feeding in dairy cows was performed using mean treatment data $(\mathrm{n}=306)$ from 50 production trials conducted in Finland $(\mathrm{n}=48)$ and Sweden $(\mathrm{n}=$ 2). Data were used to assess the effects of diet composition and certain animal characteristics on MUN and to derive relationships between MUN and the efficiency of $\mathrm{N}$ utilization for milk production and urinary $\mathrm{N}$ excretion. Relationships were developed using regression analysis based on either models of fixed factors or using mixed models that account for between-experiment variations. Dietary crude protein $(\mathrm{CP})$ content was the best single predictor of MUN and accounted for proportionately 0.778 of total variance $[\mathrm{MUN}(\mathrm{mg} / \mathrm{dL})=-14.2$ $+0.17 \times$ dietary $\mathrm{CP}$ content $(\mathrm{g} / \mathrm{kg}$ dry matter $)]$. The proportion of variation explained by this relationship increased to 0.952 when a mixed model including the random effects of study was used, but both the intercept and slope remained unchanged. Use of rumen degradable CP concentration in excess of predicted requirements, or the ratio of dietary $\mathrm{CP}$ to metabolizable energy as single predictors, did not explain more of the variation in MUN ( $R^{2}=0.767$ or 0.778 , respectively) than dietary $\mathrm{CP}$ content. Inclusion of other dietary factors with dietary CP content in bivariate models resulted in only marginally better predictions of MUN $\left(\mathrm{R}^{2}=0.785\right.$ to 0.804$)$. Closer relationships existed between MUN and dietary factors when nutrients (CP to metabolizable energy) were expressed as concentrations in the diet, rather than absolute intakes. Furthermore, both MUN and MUN secretion $(\mathrm{g} / \mathrm{d})$ provided more accurate predictions of urinary $\mathrm{N}$ excretion $\left(\mathrm{R}^{2}=\right.$ 0.787 and 0.835 , respectively) than measurements of the efficiency of $\mathrm{N}$ utilization for milk production $\left(\mathrm{R}^{2}=\right.$ 0.769). It is concluded that dietary CP content is the most important nutritional factor influencing MUN,
\end{abstract}

Received May 14, 2003.

Accepted July 15, 2003.

Corresponding author: P. Huhtanen; e-mail: pekka.huhtanen@ mtt.fi. and that measurements of MUN can be utilized as a diagnostic of protein feeding in the dairy cow and used to predict urinary $\mathrm{N}$ excretion.

(Key words: milk urea nitrogen, dairy cow, protein nutrition, diagnostic)

Abbreviation key: AAT = amino acids absorbed from the small intestine, BUN = blood urea nitrogen, $\mathbf{M E}=$ metabolizable energy, ECM = energy-corrected milk, MUNS = milk urea N secretion, $\mathbf{P B V}=$ protein balance in the rumen, RMSE = residual mean square error.

\section{INTRODUCTION}

The basic function of milk producing ruminants is to convert low-quality noncompetitive feed sources into high quality protein for human consumption. Often the amount and quality of protein absorbed from the small intestine can limit milk production (Huhtanen, 1998). However, feeding excess protein in relation to requirements increase environmental $\mathrm{N}$ emissions (Castillo et al., 2000; Frank and Swensson, 2002; Huhtanen et al., unpublished) and can impair reproductive performance (refer to Shingfield et al., 1999). Consequently, there is an urgent need for on-farm diagnostic to monitor the adequacy of protein feeding offering the opportunity to optimize the efficiency of $\mathrm{N}$ utilization with respect to both milk protein production and $\mathrm{N}$ emissions into the environment.

Blood urea nitrogen (BUN) is the major end product of $\mathrm{N}$ metabolism in ruminants, and high concentrations of it are indicative of an inefficient utilization of dietary N. However, BUN cannot be measured routinely due to difficulties in obtaining regular and reliable samples. It is well established that urea equilibrates rapidly with body fluids, including milk, and this can account for the close relationship between milk urea nitrogen (MUN) and BUN (Broderick and Clayton, 1997; Hof et al., 1997). Since milk is easily collected and can be determined accurately for urea by enzymatic or physical methods, it has often been suggested that MUN in bulk tank milk could be used as a diagnostic of on-farm efficiency of N utilization (Jonker et al., 1998; Kauffman and St-Pierre, 2001; Kohn et al., 2002). 
Variance in MUN has been shown to be related to the ratio of dietary CP to energy (Oltner and Wiktorsson, 1983; Kirchgessner et al., 1986), extent of CP degradation in the rumen and the amount of ammonia in excess of microbial $\mathrm{N}$ requirements (Ropstad et al., 1989; Roseler et al., 1993; Hof et al., 1997), and protein or energy intake in relation to feeding standards (Gustafsson and Carlsson, 1993; Carlsson and Pehrson, 1994). However, there is evidence that MUN is more closely associated with changes in dietary $\mathrm{CP}$ content than the ratio of dietary CP to energy intake, efficiency of $\mathrm{N}$ utilization, or rumen ammonia concentration (Broderick and Clayton, 1997). Even though these findings have been based on sound physiological principles, the relationships derived may not be universally applicable due to variations in nutrient intake and betweenanimal differences. Furthermore, previous evaluations of MUN fail to account for random study effects, which can lead to biased estimates of regression coefficients (St-Pierre, 2001) and have been based on data from a limited number of studies (e.g., Jonker et al., 1998; Kauffman and St-Pierre, 2001; Kohn et al., 2002).

Milk urea nitrogen has routinely been determined in a number of milk production trials conducted in Nordic countries that also measure animal and dietary characteristics. This evaluation was conducted to (1) examine the effects of diet composition and nutrient intake on MUN using mean treatment data across a wide range of nutritional circumstances, in conjunction with statistical models that accounted for random study effects, and (2) assess the potential of MUN as a predictor of urinary $\mathrm{N}$ excretion and the efficiency of dietary $\mathrm{N}$ utilization.

\section{MATERIALS AND METHODS}

\section{Datasets}

Mean treatment data were derived from 50 milk production trials that assessed 306 different diets. Trials were conducted in Finland $(\mathrm{n}=48)$ and Sweden $(\mathrm{n}=$ 2 ; refer to Appendix 1), most of which $(\mathrm{n}=42)$ were conducted as changeover designs with 3 - or 4-wk experimental periods.

\section{Experimental Diets}

Grass or grass-legume silages were fed ad libitum in all trials supplemented with concentrates offered at a flat rate (mean $8.1 \mathrm{~kg} \mathrm{DM} / \mathrm{d}$, SE 1.26), irrespective of milk yield. For statistical analysis, diet composition was characterized as ( $\mathrm{g} / \mathrm{kg} \mathrm{DM}) \mathrm{CP}$, AA absorbed from the small intestine (AAT), protein balance in the rumen (PBV), NDF, starch, NSC, lactic acid, VFA, and ammonia N. Apparent diet digestibility was determined $(\mathrm{n}=$
270) using acid insoluble ash as an internal marker (Van Keulen and Young, 1977). Nonstructural carbohydrate content was estimated as $\mathrm{OM}-(\mathrm{CP}+$ ether extract $+\mathrm{NDF}$ ). Concentrations of AAT and PBV were calculated according to the metabolizable protein system adopted in Finland (Tuori et al., 2002), where AAT represents the supply of AA available for absorption, and PBV indicates the balance of rumen degradable crude protein relative to microbial $\mathrm{N}$ requirements, providing an estimate of rumen $\mathrm{N}$ losses. Metabolizable energy (ME) content was calculated using published values for concentrate ingredients (Tuori et al., 2002), and in vivo or in vitro OM digestibility of forages. In vivo OM digestibility of silages was measured in sheep fed at maintenance $(n=13)$, or predicted in vitro using rumen fluid ( $\mathrm{n}=16$, Tilley and Terry, 1963) or a pepsincellulase $(n=25)$ based method (see Nousiainen et al., 2003).

In addition to diet composition, including silage, concentrate, and total DMI, animal measures such as daily milk and energy-corrected milk (ECM) yield, milk protein, fat and lactose concentration, live weight, and mean DIM during experiment were used. Milk urea nitrogen was determined as ammonia in composite samples according to McCullough (1967) (26 trials and 185 treatments), or Rajamäki and Rauramaa (1984) (8 trials and 39 treatments), or measured in untreated samples by an automated infrared analysis (Milcoscan IR 605 or IR 4000, FOSS Electric A/S, Denmark; 16 trials and 82 treatments).

The apparent efficiency of $\mathrm{N}$ utilization for milk protein synthesis was defined as milk N/N intake. Urinary $\mathrm{N}$ excretion was estimated as $\mathrm{N}$ intake - (milk $\mathrm{N}+$ fecal $\mathrm{N}$ output), assuming no net changes in $\mathrm{N}$ retention during each experiment. To estimate the source of MUN secretion in milk, the contribution of absorbed $\mathrm{N}$ not incorporated in milk protein was separated into ruminal $\mathrm{N}$ losses and those associated with the metabolism of absorbed AA (maintenance, milk production, and retention). In cases where PBV intake was positive, $\mathrm{N}$ surplus to microbial requirements was assumed to be completely absorbed from the rumen and converted to urea. For diets in which PBV was negative, $\mathrm{N}$ losses associated with AA metabolism were assumed to be recycled via saliva into the rumen and to satisfy microbial requirements. Nitrogen losses related to the metabolism of absorbed AA were calculated as $0.16 \times$ AAT intake $(\mathrm{g} / \mathrm{d})-$ milk $\mathrm{N}$ output $(\mathrm{g} / \mathrm{d})$.

\section{Statistical Analysis}

Relationships between MUN with animal and dietary factors were derived using the entire data or subsets, in which data were separated into studies comparing 
effects of the level of concentrate supplementation (35 comparisons, 80 diets), concentrate $\mathrm{CP}$ content (76 comparisons, 188 diets), silage fermentation quality (21 comparisons, 55 diets), or replacing grass silage with legume silage (10 comparisons, 32 diets). In studies evaluating the effects of concentrate feeding, only the level of supplementation was altered (range 2.8 to 13.5 $\mathrm{kg} \mathrm{DM} / \mathrm{d})$. For protein feeding studies, concentrates were fed at a fixed rate (mean $7.9 \mathrm{~kg} \mathrm{DM} / \mathrm{d}, \mathrm{SE} \mathrm{1.55),}$ and protein supplements replaced basal concentrate ingredients. In studies assessing the impact of silage fermentation, experimental silages were prepared from the same sward and ensiled using none, an enzyme and/or inoculant, or formic acid based additive.

Relationships between MUN and animal or dietary measurements were estimated by linear regression analysis. Furthermore, MUN was used to predict the efficiency of $\mathrm{N}$ utilization for milk production and urinary $\mathrm{N}$ excretion. Relationships obtained were assessed based on the proportion of variance accounted for by the model $\left(\mathrm{R}^{2}\right)$ and residual mean square error (RMSE).

Since a component of the variance in MUN can arise from differences in the stage of lactation, genetic merit, animal live weight, feeding strategies, and analytical techniques used to determine urea in milk, it is important to exclude these sources when the impact of nutrition is being evaluated. Therefore relationships between MUN with $\mathrm{N}$ utilization, animal, or dietary factors within the experiment were also investigated using the MIXED procedure of SAS (Littell et al., 1996) according to the following model $\mathrm{Y}_{\mathrm{ij}}=\mathrm{A}_{0}+\operatorname{Exp}_{\mathrm{i}}+\mathrm{B}_{1} \mathrm{X}_{1 \mathrm{ij}}$ $+\mathrm{B}_{2} \mathrm{X}_{2 \mathrm{ij}}+\ldots+\mathrm{e}_{\mathrm{ij}}$, where $\mathrm{A}_{0}$ is the overall intercept (fixed effect), $\operatorname{Exp}_{\mathrm{i}}$ is the random effect of experiment, $\mathrm{B}_{1}$ and $\mathrm{B}_{2}$, are the overall regression coefficients across experiments, $\mathrm{X}_{1 \mathrm{ij}}$ and $\mathrm{X}_{2 \mathrm{ij}}$, are the value $\mathrm{j}$ of the continuous variables $\mathrm{X}_{1}$ and $\mathrm{X}_{2}$, in experiment $\mathrm{i}$, and $\mathrm{e}_{\mathrm{ij}}$ represents unexplained error. In addition, some analysis was conducted using random slopes to assess the extent of RMSE attributable to the experiment. The mixed model methodology used has been described in detail (StPierre, 2001), whereas RMSE and the coefficient of determination $\left(\mathrm{R}^{2}\right)$ were derived from single factor regression between values predicted by the mixed model and measured values. Furthermore, $\mathrm{R}^{2}$ values were also calculated to estimate the proportion of variation explained within the experiment, where: $R_{\text {within }}^{2}=\left[\left(R^{2}-\right.\right.$

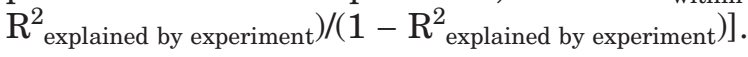

\section{RESULTS}

\section{Diet Composition}

A description of the entire data used for evaluation is presented in Table 1. Most variables exhibited large variance that was normally distributed. On average, cows were 109 DIM (range 42 to 226) and of mean $579 \mathrm{~kg}$ of live weight (range 468 to 657). Diets were predominantly based on grass silage supplemented with a wide range of energy (cereals and cereal byproducts) and protein (mainly rapeseed meal) supplements. Diets contained mean CP and ME concentrations of 160 $\mathrm{g} / \mathrm{kg} \mathrm{DM}$ (range 111 to 249 , coefficients of variation $11.9 \%$ ), and $11.3 \mathrm{MJ} / \mathrm{kg} \mathrm{DM}$ (range 9.6 to 12.2 , CV $4.2 \%)$, respectively.

\section{Feed Intake, Milk Production, and Composition}

Total DMI was on average $19.8 \mathrm{~kg} / \mathrm{d}$ but varied between 12.9 and $23.6 \mathrm{~kg} / \mathrm{d}$, and mean CP intake was $3167 \mathrm{~g} / \mathrm{d}$ (range 1697 to 4903 , proportionately 0.559 from forage and 0.441 from concentrate CP). Both apparent total tract $\mathrm{OM}$ (mean 0.716 ) and $\mathrm{N}$ digestibility (mean 0.685) were typical for diets based on high quality forages supplemented with modest levels of concentrates. Mean daily milk and ECM yield were 27.8 (range 13.0 to 36.3 ) and $29.0 \mathrm{~kg} / \mathrm{d}$ (range 15.6 to 38.1 ), respectively, whereas MUN (mean $13.3 \mathrm{mg} / \mathrm{dL}$ ) varied (CV $26.0 \%$ ) between 3.8 and $27.0 \mathrm{mg} / \mathrm{dL}$.

\section{Relationships with MUN Derived Using the Entire Dataset}

Both fixed and mixed regression models indicated a close association between dietary CP and MUN (Figure 1, Table 2). Slopes based on single factor regression (0.172), or using mixed models that assumed random intercepts (0.169), or both random intercepts and slopes $(0.165)$ were similar. However, $R^{2}$ values of regressions were much higher using mixed models. Inclusion of dietary energy content in addition to $\mathrm{CP}$ within bivariate models resulted in only marginal improvements in $\mathrm{R}^{2}$ values compared with dietary $\mathrm{CP}$ content alone. Overall, bivariate models indicated that at constant dietary CP content, increases in dietary NDF content were associated with marginally higher MUN (slope $0.007 \mathrm{mg} / \mathrm{dL}$ per $1 \mathrm{~g} / \mathrm{kg}$ DM increase in NDF), whereas increases in dietary NSC content were associated with slight decreases in MUN (slope $-0.007 \mathrm{mg} / \mathrm{dL}$ per $1 \mathrm{~g} /$ $\mathrm{kg}$ DM increase in NSC).

The relationship between MUN and dietary PBV content was similar to that for dietary CP concentrations $\left(\mathrm{R}_{\text {within }}^{2} 0.860\right.$ vs. 0.825 ), but the slope was higher for PBV (0.21 and $0.17 \mathrm{mg} / \mathrm{dL}$ per $\mathrm{g} / \mathrm{kg} \mathrm{DM}$, respectively), and the intercept suggested that when PBV was zero (i.e., no net absorption of, ammonia from the rumen) MUN was close to $12 \mathrm{mg} / \mathrm{dL}$. Expressing dietary CP as a ratio to energy content $(\mathrm{CP} / \mathrm{ME})$ did not improve upon 
Table 1. Description of diet composition, nutrient intake, and milk production data used for evaluation.

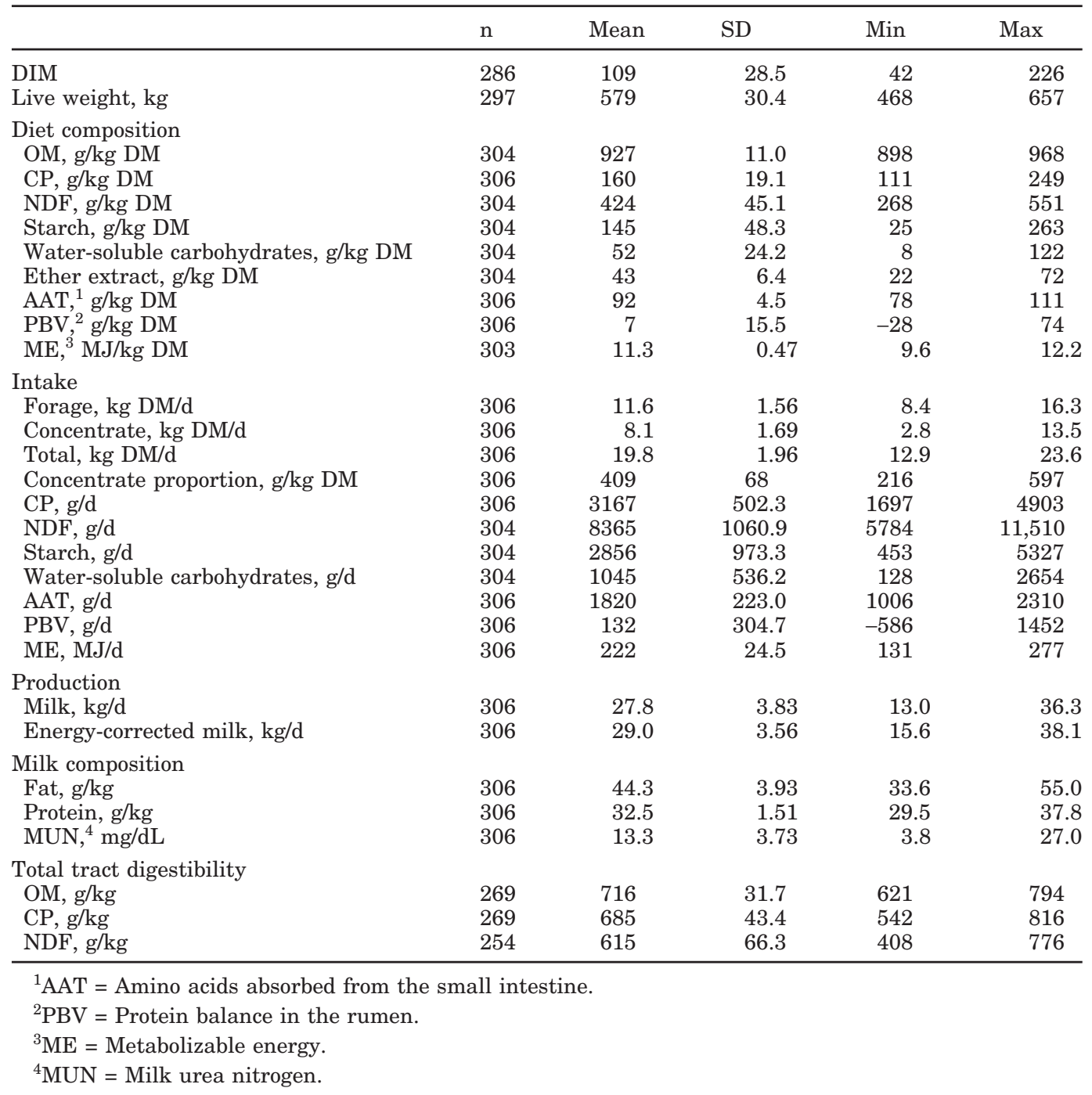

the relationship obtained with dietary $\mathrm{CP}$ concentration.

The relationship with MUN and CP intake was much weaker than for dietary CP content based on single regression analysis $\left(R^{2}=0.451\right.$ vs. 0.778$)$ or using mixed models ( $\mathrm{R}^{2}$ within 0.663 vs. 0.860$)$. Bivariate models that included DM or ME intake in addition to $\mathrm{CP}$ intake explained much more of the variation in MUN than CP intake alone $\left(\mathrm{R}^{2}{ }_{\text {within }}=0.871\right.$ and 0.861 vs. 0.663 , respectively). Use of a more theoretically sound description of dietary protein in terms of PBV and AAT, or both these parameters and calculated energy balance, did not improve upon these relationships. Milk urea nitrogen was increased in response to both increased AAT and PBV intake, but the slope for PBV was markedly higher than for AAT when both effects were used in the same mixed model $(0.002$ vs. $0.011 \mathrm{mg} / \mathrm{dL}$ per gram AAT or PBV). However, assuming zero changes in $\mathrm{N}$-retention and expressing surplus dietary $\mathrm{N}$ from ruminal (PBV-N) or tissue metabolism (AAT-N - milk $\mathrm{N}$ ) on a DMI basis (g N/kg DM) indicated that both sources had similar effects on MUN (1.19 vs. $1.21 \mathrm{mg} /$ dL per gram N/kg DMI, data not presented).

Use of the mixed effect model (Table 3) indicated that the intake of rumen degradable $\mathrm{N}$ in excess of microbial requirements (PBV-N) increased MUN secretion more than absorbed AA-N intake (0.018 vs. $0.012 \mathrm{~g} / \mathrm{g} \mathrm{N}$ intake; $P<0.001$ ), a finding that also held true using the fixed effect model. However, the impact of $\mathrm{N}$ losses on MUN secretion due to ammonia $\mathrm{N}$ absorption from the rumen or AAT-N intake in excess of requirements (AAT-N intake - milk protein $\mathrm{N}$ output) were of similar magnitude.

Silage fermentation characteristics had minor, albeit, significant effects on MUN (data not shown). Mixed model analysis indicated that MUN increased by 0.17 


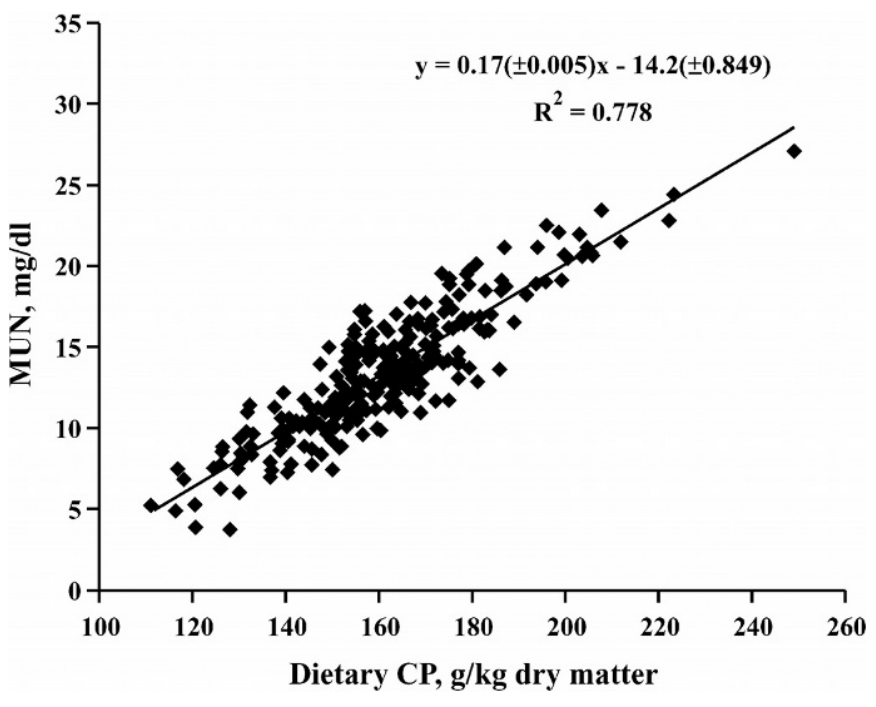

Figure 1. Association between dietary $\mathrm{CP}$ content and MUN for the entire evaluation dataset $(n=306)$.

$(P<0.001)$ or $0.04 \mathrm{mg} / \mathrm{dl}(P<0.01)$ per $\mathrm{g} / \mathrm{kg} \mathrm{DM}$ increase in dietary VFA or lactic acid content, respectively. In addition, MUN was also increased $0.03 \mathrm{mg} / \mathrm{L}(P=0.03)$ in response to $1 \mathrm{~g} / \mathrm{kg}$ increases in silage ammonia $\mathrm{N}$ concentrations.

The outcome of the mixed effect (random intercepts) model including variables that significantly $(P<0.10)$ explained variation in MUN is shown in Table 4. Overall, the model accounted for proportionally 0.957 of total variance, and 0.901 of within experiment variation in MUN. Dietary CP content was the most important nutritional factor in the model. Both dietary energy content and the ratio of AAT to $\mathrm{CP}$ were inversely related with MUN, whereas starch and NDF concentrations had slightly positive effects. Concentrations of urea also increased $(P=0.04)$ when milk protein content decreased and for silages prepared from sward regrowths relative to the corresponding primary growths $(P=$ 0.008 ). Use of a formic acid based additive during ensiling was associated with a decrease in MUN compared with silages conserved using none or enzyme and/or inoculant additives. Inclusion of energy balance or milk yield as fixed factors did not account for more of the variation in MUN, and the respective slopes were not significant $(P>0.10)$.

\section{Relationships with MUN Derived Using Data Subsets}

Different data subsets used to assess the reliability of MUN predictions indicated that MUN responses to increases in dietary $\mathrm{CP}$ concentration were much the same, irrespective of dietary manipulation (Table 5). However, the regression coefficient derived between MUN and dietary CP concentration was marginally lower than the overall mean coefficient when protein content was increased through partial or complete replacement of grass silage with legume silage $(0.14 \mathrm{vs}$. $0.17 \mathrm{mg} / \mathrm{dL}$ per grams of CP).

The coefficient obtained using the ratio of $\mathrm{CP}$ to $\mathrm{ME}$ was higher for studies examining the impact of protein supplementation compared with other data subsets. However, relationships obtained using bivariate models indicated similar coefficients for CP and ME intakes, irrespective of data source.

\section{Nitrogen Utilization and Urinary $\mathbf{N}$ Excretion}

A negative association existed between MUN and the efficiency of $\mathrm{N}$ utilization for milk protein synthesis (Table 6), but dietary CP concentration explained more of the variation in $\mathrm{N}$ efficiency than $\mathrm{MUN}\left(\mathrm{R}^{2}\right.$ within 0.769 vs. 0.805). For both fixed and mixed models, inclusion of milk yield improved the accuracy of MUN based predictions of urinary $\mathrm{N}$ excretion and efficiency of $\mathrm{N}$ utilization. Effects of milk yield and MUN were combined by calculating daily MUN secretion (MUNS, g/d), which explained proportionately 0.835 of within experiment variation in urinary $\mathrm{N}$ excretion. Furthermore, this prediction was associated with an RMSE of $14.7 \mathrm{~g} \mathrm{~N}$ per day. For data subsets based on studies assessing concentrate feeding (1) or protein supplementation (2), the following regression equations were derived using mixed effects models:

(1) Urinary $\mathrm{N}$ excretion $(\mathrm{g} / \mathrm{d})=79.6( \pm 10.30)+$ 803( \pm 62.6$)$ MUNS $\left(\mathrm{R}_{\text {within }}^{2} 0.805, \mathrm{RMSE}=9.6\right)$.

(2) Urinary $\mathrm{N}$ excretion $(\mathrm{g} / \mathrm{d})=32.0( \pm 5.25)+$ 1009( \pm 23.6$)$ MUNS $\left(R_{\text {within }}^{2}\right.$ 0.945, RMSE $\left.=7.7\right)$.

In common with $\mathrm{N}$ efficiency, dietary $\mathrm{CP}$ concentration provided a more accurate prediction of urinary $\mathrm{N}$ excretion than MUN. Use of MUNS in combination with dietary $\mathrm{CP}$ content resulted in only marginal improvements in the prediction of urinary $\mathrm{N}$ excretion for both fixed and random effect models (Table 6).

\section{DISCUSSION}

\section{Physiological Basis of MUN}

Milk urea nitrogen has often been used to provide an indication of the efficiency of $\mathrm{N}$ utilization and to predict $\mathrm{N}$ emissions into the environment. Since urea equilibrates rapidly between body fluids (DePeters and Ferguson, 1992) and enters the mammary gland by diffusion, concentrations of urea in plasma and milk are generally closely associated (Oltner and Wiktorsson, 
Table 2. Predictions of milk urea N (mg/dl) according to linear fixed or mixed effects regression models based on diet composition, nutrient intake, or milk yield as independent regression variables (model: $\mathrm{Y}=\mathrm{A}+\mathrm{BX}_{1}+\mathrm{CX}_{2}$, where $\mathrm{A}$ is the intercept, $\mathrm{B}$ and $\mathrm{C}$ represent regression variables, and Exp is the random effects of experiment used in mixed effects regression models, $\mathrm{n}=306$ ).

\begin{tabular}{|c|c|c|c|c|c|c|c|c|c|c|c|c|c|}
\hline $\mathrm{X}_{1}, \mathrm{X}_{2}$ & $\mathrm{~A}$ & $\mathrm{SE}$ & $P$-value & $\mathrm{B}$ & $\mathrm{SE}$ & $P$-value & $\mathrm{C}$ & $\mathrm{SE}$ & $P$-value & RMSE & $\mathrm{CV}$ & $\mathrm{R}^{2}$ & $\begin{array}{l}\mathrm{R}^{2} \\
\text { within } \\
\text { Exp }\end{array}$ \\
\hline \multicolumn{14}{|l|}{ Diet composition } \\
\hline CP, Exp & -13.7 & 0.71 & $<0.001$ & 0.17 & 0.004 & $<0.001$ & & & $<0.001$ & 0.81 & 6.1 & 0.952 & 0.860 \\
\hline $\mathrm{CP}, \mathrm{ME}^{2}$ & 1.1 & 2.54 & 0.665 & 0.18 & 0.005 & $<0.001$ & -1.421 & 0.2229 & $<0.001$ & 1.65 & 12.4 & 0.804 & \\
\hline CP, ME, Exp & -2.2 & 2.56 & 0.402 & 0.17 & 0.004 & $<0.001$ & -1.032 & 0.2204 & $<0.001$ & 0.79 & 5.9 & 0.955 & 0.869 \\
\hline $\mathrm{CP}, \mathrm{NDF}^{3}$ & -18.2 & 1.43 & $<0.001$ & 0.18 & 0.005 & $<0.001$ & 0.008 & 0.0023 & 0.001 & 1.72 & 12.9 & 0.786 & \\
\hline CP, NSC, Exp & -10.9 & 1.11 & $<0.001$ & 0.16 & 0.004 & $<0.001$ & -0.006 & 0.0020 & 0.002 & 0.80 & 6.0 & 0.954 & 0.866 \\
\hline $\mathrm{PBV}^{5}$ & 11.9 & 0.11 & $<0.001$ & 0.21 & 0.007 & $<0.001$ & & & & 1.80 & 13.5 & 0.767 & \\
\hline PBV, Exp & 11.8 & 0.26 & $<0.001$ & 0.21 & 0.006 & $<0.001$ & & & & 0.91 & 6.8 & 0.940 & 0.825 \\
\hline CP/ME & -13.7 & 0.83 & $<0.001$ & 1.90 & 0.058 & $<0.001$ & & & $<0.001$ & 1.75 & 13.2 & 0.778 & \\
\hline CP/ME, Exp & -12.5 & 0.72 & $<0.001$ & 1.82 & 0.047 & $<0.001$ & & & $<0.001$ & 0.87 & 6.5 & 0.946 & 0.841 \\
\hline \multicolumn{14}{|l|}{ Intake } \\
\hline PBV, Exp & 11.8 & 0.25 & $<0.001$ & 0.011 & 0.0003 & $<0.001$ & & & $<0.001$ & 0.89 & 6.7 & 0.943 & 0.832 \\
\hline $\mathrm{CP}, \mathrm{DM}$ & 14.3 & 1.02 & $<0.001$ & 0.009 & 0.0003 & $<0.001$ & -1.439 & 0.0681 & $<0.001$ & 1.76 & 13.2 & 0.778 & \\
\hline CP, DM, Exp & 17.7 & 1.21 & $<0.001$ & 0.009 & 0.0002 & $<0.001$ & -1.618 & 0.0729 & $<0.001$ & 0.78 & 5.9 & 0.956 & 0.871 \\
\hline $\mathrm{AAT}^{6}, \mathrm{PBV}$ & 9.0 & 0.81 & $<0.001$ & 0.002 & 0.0004 & $<0.001$ & 0.011 & 0.0003 & $<0.001$ & 1.71 & 12.9 & 0.789 & \\
\hline AAT, PBV, Exp & 8.8 & 0.96 & $<0.001$ & 0.002 & 0.0005 & 0.001 & 0.011 & 0.0003 & $<0.001$ & 0.87 & 6.5 & 0.945 & 0.839 \\
\hline \multicolumn{14}{|l|}{ Yield } \\
\hline Milk $^{7}$ & 9.7 & 1.55 & $<0.001$ & 0.13 & 0.055 & 0.020 & & & $<0.001$ & 3.70 & 27.8 & 0.014 & \\
\hline Milk, Exp & 3.9 & 2.41 & 0.111 & 0.35 & 0.085 & $<0.001$ & & & $<0.001$ & 2.08 & 15.6 & 0.687 & 0.082 \\
\hline $\begin{array}{l}{ }^{1} \mathrm{CP}=\text { Crude pro } \\
{ }^{2} \mathrm{ME}=\text { Metaboli } \\
{ }^{3} \mathrm{NDF}=\text { Neutral } \\
{ }^{4} \mathrm{NSC}=\text { Nonstru } \\
{ }^{5} \mathrm{PBV}=\text { Protein } \\
{ }^{6} \mathrm{AAT}=\text { Absorbe } \\
{ }^{7} \mathrm{Milk}=\text { Milk yie }\end{array}$ & $\begin{array}{l}\text { tein }(\mathrm{g} / \mathrm{l} \\
\text { able en } \\
\text { deterge } \\
\text { ctural c } \\
\text { olance } \\
\text { amino } \\
\text { d }(\mathrm{kg} / \mathrm{d}\end{array}$ & $\begin{array}{l}\text { DM). } \\
\text { rgy (M } \\
\text { t fiber } \\
\text { rbohyd } \\
\text { alue ( } \\
\text { acids ( }\end{array}$ & $\begin{array}{l}/ \mathrm{kg} D M) \\
\mathrm{g} / \mathrm{kg} \mathrm{DM}) \\
\text { ates }(\mathrm{g} / \mathrm{kg} \\
\mathrm{kg} \mathrm{DM}) \\
\text { (d). }\end{array}$ & $\mathrm{DM})$. & & & & & & & & & \\
\hline
\end{tabular}

1983; Roseler et al., 1993; Broderick and Clayton, 1997; Kauffman and St-Pierre, 2001). Milk urea is also derived from arginine catabolism in the mammary gland (Annison, 1983), but this does not appear to be quantitatively important.
The intake of PBV had a greater effect on MUN than AAT (Table 2), which may reflect the close association between AAT and energy intake. Including ME intake as an additional independent variable reduced the difference between coefficients for AAT and PBV (MUN

Table 3. Predictions of milk urea nitrogen secretion ( $\mathrm{g} / \mathrm{d}$ ) based on PBV-N and AAT-N intake according to fixed or mixed effects linear regression models; $\mathrm{Y}=\mathrm{A}+\mathrm{BX}_{1}+\mathrm{CX}_{2}$, where $\mathrm{A}$ is the intercept, $\mathrm{B}$ and $\mathrm{C}$ represent regression variables, and Exp is the random effect of experiment used in mixed effects regression models, $\mathrm{n}=306)$.

\begin{tabular}{|c|c|c|c|c|c|c|c|c|c|c|c|c|}
\hline $\mathrm{X}_{1}, \mathrm{X}_{2}$ & A & $\mathrm{SE}$ & $P$-value & B & $\mathrm{SE}$ & $P$-value & $\mathrm{C}$ & $\mathrm{SE}$ & $P$-value & RMSE & $\mathrm{R}^{2}$ & $\begin{array}{l}\mathrm{R}^{2} \\
\text { within } \\
\operatorname{Exp}\end{array}$ \\
\hline PBV-NI, ${ }^{1}$ AAT-NI ${ }^{2}$ & -1.05 & 0.249 & $<0.001$ & 0.019 & 0.0006 & $<0.001$ & 0.015 & 0.0009 & $<0.001$ & 0.528 & 0.8096 & \\
\hline PBV-NI, Excess AAT-NI ${ }^{3}$ & 0.55 & 0.263 & 0.036 & 0.019 & 0.0008 & $<0.001$ & 0.018 & 0.0017 & $<0.001$ & 0.641 & 0.7191 & \\
\hline PBV-NI, Excess AAT-NI, Exp & 0.81 & 0.247 & 0.002 & 0.018 & 0.0006 & $<0.001$ & 0.016 & 0.0016 & $<0.001$ & 0.262 & 0.9532 & 0.769 \\
\hline
\end{tabular}

${ }^{1} \mathrm{PBV}-\mathrm{NI}=$ Excess rumen degradable $\mathrm{N}$ intake $(\mathrm{g} / \mathrm{d})$.

${ }^{2}$ AAT-NI $=$ Intake of absorbed amino acid $\mathrm{N}(\mathrm{g} / \mathrm{d})$.

${ }^{3}$ Excess AAT-NI $=$ Milk protein $\mathrm{N}-$ intake of absorbed amino acid $\mathrm{N}(\mathrm{g} / \mathrm{d})$. 
Table 4. Identification of dietary and production parameters that made a significant contribution in regressions with milk urea nitrogen concentration $(\mathrm{mg} / \mathrm{dl})$ according to mixed effects linear regression models (experiment used as a random factor, $\mathrm{n}=259$, root mean square error $=0.68, \mathrm{R}^{2}=0.957$ ).

\begin{tabular}{lllcc}
\hline Effect & $\begin{array}{l}\text { Estimate } \\
(\mathrm{mg} / \mathrm{dl})\end{array}$ & $\begin{array}{l}\text { Standard } \\
\text { error }\end{array}$ & $t$ Value & $\operatorname{Pr}>|\mathrm{t}|$ \\
\hline Intercept $(\mathrm{g} / \mathrm{kg} \mathrm{DM})$ & 9.6 & 6.36 & 1.5 & 0.1405 \\
$\mathrm{CP}(\mathrm{g} / \mathrm{kg} \mathrm{DM})$ & 0.17 & 0.012 & 13.72 & $<0.001$ \\
$\mathrm{AAT} / \mathrm{CP}^{1}$ & -0.01 & 0.005 & -2.62 & 0.0094 \\
$\mathrm{ME}^{2}$ & -1.36 & 0.346 & -3.92 & 0.0001 \\
$\mathrm{Starch}(\mathrm{g} / \mathrm{kg} \mathrm{DM})$ & 0.02 & 0.003 & 5.65 & $<0.001$ \\
$\mathrm{NDF}^{3}$ (g/kg DM) & 0.01 & 0.004 & 1.84 & 0.0669 \\
Milk protein content $(\mathrm{g} / \mathrm{kg})_{\text {Silage harvest }^{4}}^{-0.18}$ & 0.089 & -2.05 & 0.0412 \\
Silage additive $^{5}$ & -0.68 & 0.253 & -2.7 & 0.0076 \\
& -0.55 & 0.227 & -2.4 & 0.0174 \\
\hline
\end{tabular}

\footnotetext{
${ }^{1}$ Amino acids absorbed $(\mathrm{g})$ from the small intestine per $\mathrm{kg} \mathrm{CP}$.

${ }^{2}$ Metabolizable energy (MJ/kg DM).

${ }^{3}$ Neutral detergent fiber ( $\left./ \mathrm{kg} \mathrm{DM}\right)$.

${ }^{4}$ Silage harvest refers to a comparison of silages harvested from primary or corresponding regrowths of grass or grass legume swards.

${ }^{5}$ Silage additive refers to a comparison of silages prepared without additive or a biological inoculant or formic acid based ensiling additive.
}

$(\mathrm{mg} / \mathrm{dl})=10.4( \pm 0.90)+0.007( \pm 0.00015) \times \mathrm{AAT}$ intake $(\mathrm{g} / \mathrm{d})+0.010( \pm 0.00037) \times \mathrm{PBV}$ intake $(\mathrm{g} / \mathrm{d})-$ $0.047( \pm 0.0136) \times \mathrm{ME}$ intake $(\mathrm{MJ} / \mathrm{d}))$. This relationship suggests that each gram of absorbed $\mathrm{N}$ derived from AA increased MUN to a lesser extent than that from rumen ammonia, a finding consistent with a $50 \%$ higher coefficient for rumen degradable than undegraded $\mathrm{N}$ intake (DePeters and Ferguson, 1992).

Prediction of MUN secretion based on PBV-N and AAT-N intake also suggests that absorption of $\mathrm{N}$ from ruminal ammonia has a markedly greater impact than tissue AA catabolism (Table 3). However, absorbed AA

Table 5. Predictions of milk urea nitrogen $(\mathrm{mg} / \mathrm{dl})$ based on mixed linear effects regression models $\left(\mathrm{Y}=\mathrm{A}+\mathrm{BX}_{1}+\mathrm{CX}_{2}\right)$ in studies where nutrient intake was manipulated by the level of concentrate feeding, protein supplementation level, forage type (legume vs. grass silages), or silage fermentation quality. (Experiment was used as random factor.)

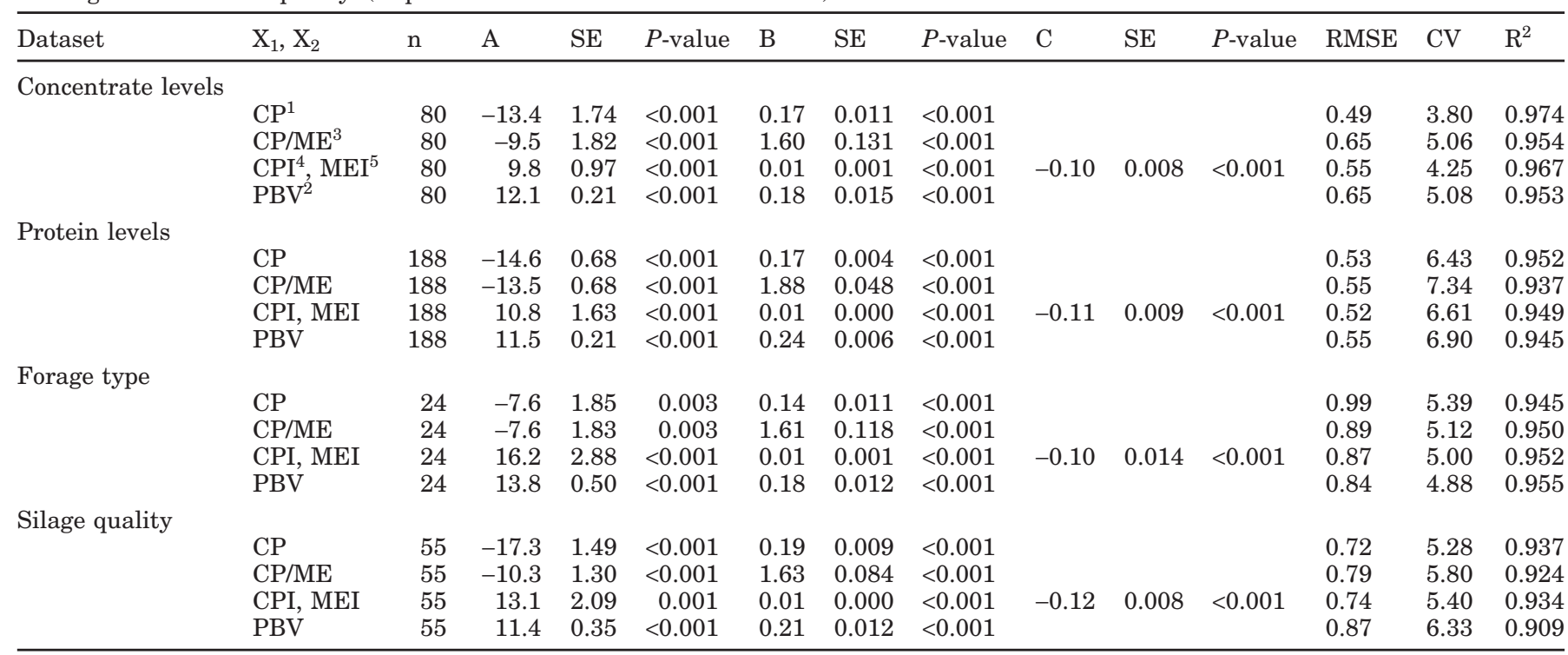

\footnotetext{
${ }^{1} \mathrm{CP}=$ Crude protein $(\mathrm{g} / \mathrm{kg}$ dry matter $\mathrm{DM})$.

${ }^{2} \mathrm{PBV}=$ Protein balance value $(\mathrm{g} / \mathrm{kg} \mathrm{DM})$.

${ }^{3} \mathrm{ME}=$ Metabolizable energy ( $\left.\mathrm{MJ} / \mathrm{kg} \mathrm{DM}\right)$.

${ }^{4} \mathrm{CPI}=$ Crude protein intake $(\mathrm{g} / \mathrm{d})$.

${ }^{5} \mathrm{MEI}=$ Metabolizable energy intake (MJ/d).
} 
Table 6. Predictions of the efficiency of nitrogen $(\mathrm{N})$ utilization for milk protein synthesis (g/kg $\mathrm{N}$ intake) and urinary $\mathrm{N}$ excretion (g/d) based on $\mathrm{MUN}^{1}$ or daily MUN secretion, dietary CP content and milk yield according to linear fixed or mixed effects regression models; $\mathrm{Y}=\mathrm{A}+\mathrm{BX}_{1}+\mathrm{CX}_{2}$, where $\mathrm{A}$ is the intercept, $\mathrm{B}$ and $\mathrm{C}$ represent regression variables, and Exp is the random effect of experiment used in mixed effects regression models, $(n=306)$.

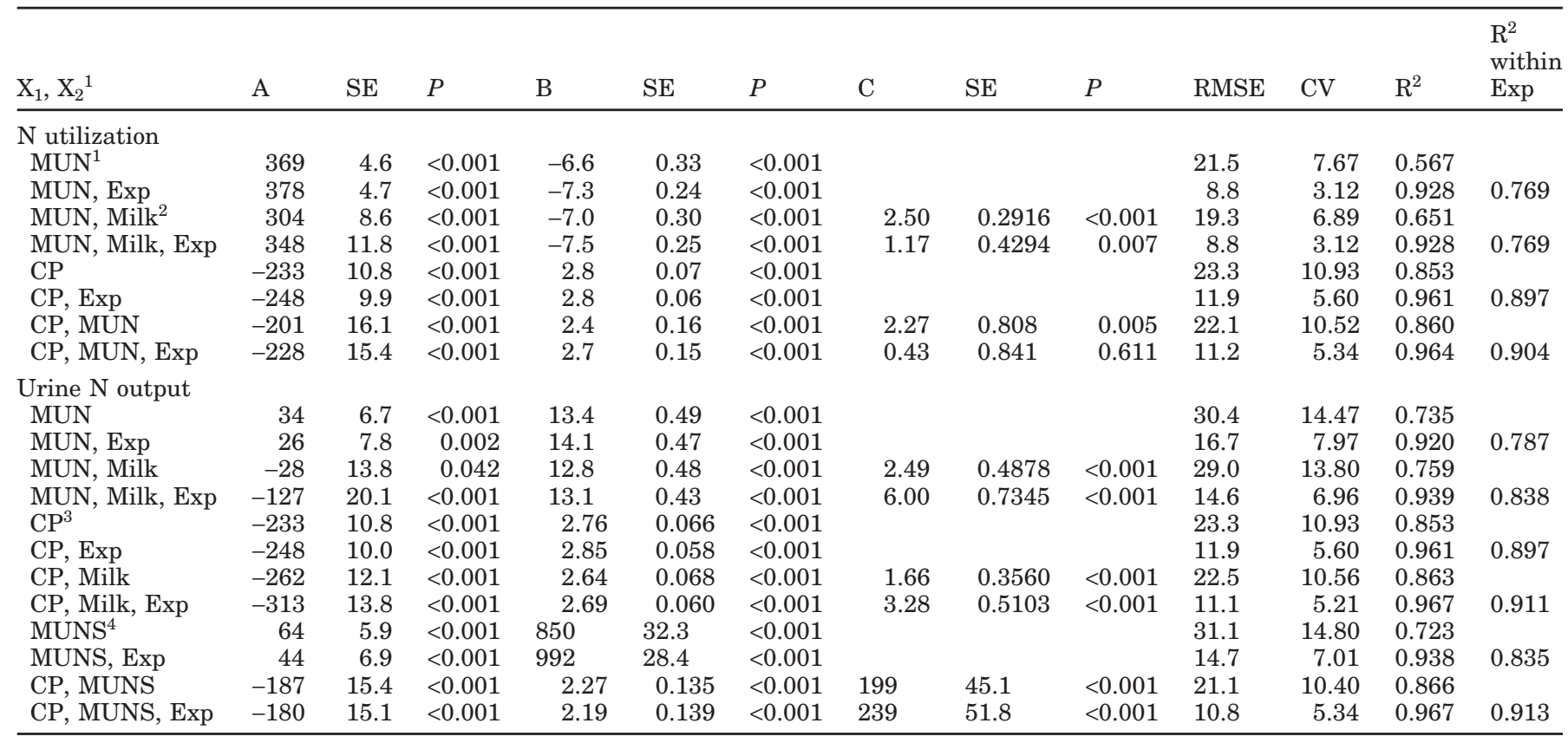

${ }^{1} \mathrm{MUN}=$ Milk urea nitrogen $(\mathrm{mg} / \mathrm{dl})$.

${ }^{2}$ Milk = Milk yield $(\mathrm{kg} / \mathrm{d})$.

${ }^{3} \mathrm{CP}=$ Diet crude protein content $(\mathrm{g} / \mathrm{kg} \mathrm{DM})$.

${ }^{4} \mathrm{MUNS}=$ Milk urea nitrogen secretion $(\mathrm{g} / \mathrm{d})$.

not utilized for milk protein synthesis had similar effects on milk urea $\mathrm{N}$ yield as ruminal $\mathrm{N}$ losses. This finding is not consistent with the view that the contribution of urea in biological fluids from AA absorption and subsequent metabolism is relatively minor (Hof et al., 1997; Schepers and Meijer, 1998). Based on theoretical considerations, these sources would be expected to have similar effects on MUN, because both ammonia $\mathrm{N}$ absorbed from the rumen and absorbed AA N not utilized for milk protein synthesis, or retained in body tissues, are metabolized to urea in the liver. Furthermore, MUN has increased in response to postruminal casein infusions in cows fed grass silage based diets (Huhtanen et al., 1997; Vanhatalo et al., 2003), strongly suggesting that AA catabolism is a significant source of BUN and MUN. Consistent with regression coefficients obtained in this evaluation, both ruminal and duodenal infusions of casein have increased MUN, but the response to ruminal infusions was higher (Khalili and Huhtanen, 2002), due to higher milk protein secretion and smaller losses of absorbed $\mathrm{N}$.

\section{The Effect of Diet on MUN}

For both fixed and mixed models, dietary CP concentration was the best single predictor of MUN, which is in direct contrast to a number of studies identifying the dietary ratio of $\mathrm{CP}$ to energy as the most important nutritional factor affecting MUN (e.g., Oltner and Wiktorsson, 1983; Kirchgessner et al., 1986). Oltner and Wiktorsson (1983) postulated that MUN was more closely associated with the ratio of $\mathrm{CP}$ to energy in the diet. However, further interpretation of mean treatment data of this study indicated that the relationship between MUN with dietary CP content $\left(\mathrm{R}^{2}=0.92\right)$ was as strong as that for the CP/ME ratio $\left(R^{2}=0.92\right)$. Similar findings can also be explained by variations in the $\mathrm{CP} /$ $\mathrm{ME}$ ratio being confounded with dietary $\mathrm{CP}$ concentrations, because increases in energy intake were associated with concomitant decreases in protein supplementation. Broderick and Clayton (1997) also reported marginally closer relationships between MUN with dietary $\mathrm{CP}$ content than the ratio of $\mathrm{CP}$ to net energy for lactation. However, within the current dataset, differences in dietary $\mathrm{CP}\left(\mathrm{R}^{2}=0.89\right)$ rather than ME content $\left(\mathrm{R}^{2}=\right.$ 0.03 ), were the major source of variation in the ratio of dietary $\mathrm{CP}$ to $\mathrm{ME}$. Furthermore, true variance in dietary ME concentrations may be lower than estimates suggest, due to negative associative effects of digestion resulting in the increase in energy content with more intensive concentrate feeding being lower than expected (Huhtanen, 1998). 
It has been suggested that a restriction in energy supply increases MUN (Kirchgessner et al., 1986), but there was no evidence of a close positive association with calculated energy balance based on the current evaluation. This apparent discrepancy may reflect energy balance being confounded with dietary $\mathrm{CP}$ content in many studies.

Use of both dietary AAT and PBV as independent variables in bivariate models would be expected to account for more variation in MUN than dietary $\mathrm{CP}$, but this evaluation does not support this (Table 2). The lack of improvement in the prediction of MUN suggests that the errors in estimating rumen degradable and undegradable protein outweigh the potential benefits in accounting for different physiological sources of urea secreted in milk. Even though AAT and PBV content failed to explain substantially more of the variance in MUN than CP content for the entire dataset, individual studies have established that MUN is also related to the quality of dietary protein. In a recent comparison over a wide range of inclusion rates, iso-nitrogenous supplements of heat-treated rapeseed expeller elicited higher milk protein and lower MUN responses compared with solvent-extracted soybean meal in cows fed grass silage based diets (Shingfield et al., accepted). Similarly, provision of comparable amounts of dietary $\mathrm{N}$ as rapeseed expeller enhanced milk protein output and reduced secretion of urea in milk, compared with dietary urea supplements or the use of higher $\mathrm{N}$ fertilizer application rates to increase grass silage CP content (Shingfield et al., 2001).

Irrespective of the model or dataset used, the intercept of the regression between dietary PBV concentration (or PBV intake) and MUN was approximately 11.7 $\mathrm{mg} / \mathrm{dL}$, suggesting at this concentration the availability of degradable $\mathrm{N}$ and energy supply in the rumen are essentially balanced. A very similar value of $10.7 \mathrm{mg} /$ dL has been derived based on the metabolizable protein system adopted in the Netherlands (Hof et al., 1997). However, measurements of microbial protein entering the omasal canal have suggested that microbial $\mathrm{N}$ requirements can be satisfied (Ahvenjärvi et al., 1999, 2002) even for diets containing negative amounts of PBV based on the Finnish metabolizable protein system (Tuori et al., 2002).

\section{Practical Applications of MUN}

Milk urea nitrogen can be relatively easily analyzed in bulk tank or individual milk samples of herds participating in herd improvement schemes (see Godden et al., 2000). This evaluation supports the suggestion that measurements of MUN could be used to assess the adequacy of protein feeding in dairy cows and the efficiency of $\mathrm{N}$ utilization for milk production (Broderick and Clayton, 1997; Jonker et al., 1998 and 2002; Kohn et al., 2002).

Of all the components assessed, dietary CP content was the most influential with respect to MUN and could therefore be used to predict $\mathrm{CP}$ concentrations of diets fed on-farm. Based on measurements from all experiments and diets $(\mathrm{n}=306)$ dietary $\mathrm{CP}$ content was accurately predicted from $\mathrm{MUN}$ as: $\mathrm{CP}(\mathrm{g} / \mathrm{kg} \mathrm{DM})=99.8(1.9)$ $+4.5( \pm 0.01) \times \mathrm{MUN}(\mathrm{mg} / \mathrm{dL})\left(\mathrm{R}^{2}=0.779 ; \mathrm{RMSE} 9.0 \mathrm{~g} / \mathrm{kg}\right.$ $\mathrm{DM})$. Both the intercept (93.4) and regression coefficient (5.0) were similar when the effects of between-experiment variations were omitted or taken into account, whereas the RMSE of 9.0 (g/ $/ \mathrm{kg} \mathrm{DM})$ is sufficiently small to suggest that this equation could be used to assess protein adequacy under most practical feeding situations. In spite of a higher intercept and regression coefficient, this prediction is consistent with that from an earlier evaluation of the potential of MUN to predict on-farm dietary CP content (Broderick and Clayton, 1997). Even though these parameters are different, due to variations in mean dietary $\mathrm{CP}$ content and a tendency for curvilinear association with MUN at high CP concentrations in the diet $(P=0.01$ for quadratic slope in data subset of legume forages), this does not necessarily negate the use of MUN measurements, provided that the prediction equation is applied to similar nutritional circumstances under which it was developed. For example, when comparing measured MUN concentrations (Frank and Swensson, 2002) and those estimated based on the relationship between dietary $\mathrm{CP}$ and MUN (Table 2), a close correlation existed between observed and predicted values $\left(R^{2}=0.95, R M S E=0.74\right)$.

In addition to assessing dietary $\mathrm{CP}$ content, measurements of MUN may also yield useful information concerning the utilization of dietary rumen degradable protein. This evaluation suggests that for diets based on grass silage, a MUN value of $11.7 \mathrm{mg} / \mathrm{dL}$ is consistent with the $\mathrm{N}$ requirements of rumen microbes being satisfied. Because recycling of $\mathrm{N}$ into the rumen was not accounted for, a lower concentration may well be adequate. A quadratic relationship between MUN and milk protein yield (Figure 2) indicates that increases in milk protein yield could be expected in response to high quality protein supplements beyond MUN concentrations of $11.7 \mathrm{mg} / \mathrm{dL}$. Even though production responses can be attained above MUN values of $16 \mathrm{mg} / \mathrm{dL}$, this occurs at the expense of a reduction in the efficiency of $\mathrm{N}$ utilization (Figure 2). The implication is that establishing recommended values for MUN is heavily dependent on the criteria being considered for optimization (i.e., recommendations for milk protein production may not necessarily coincide with those regarded optimal with 


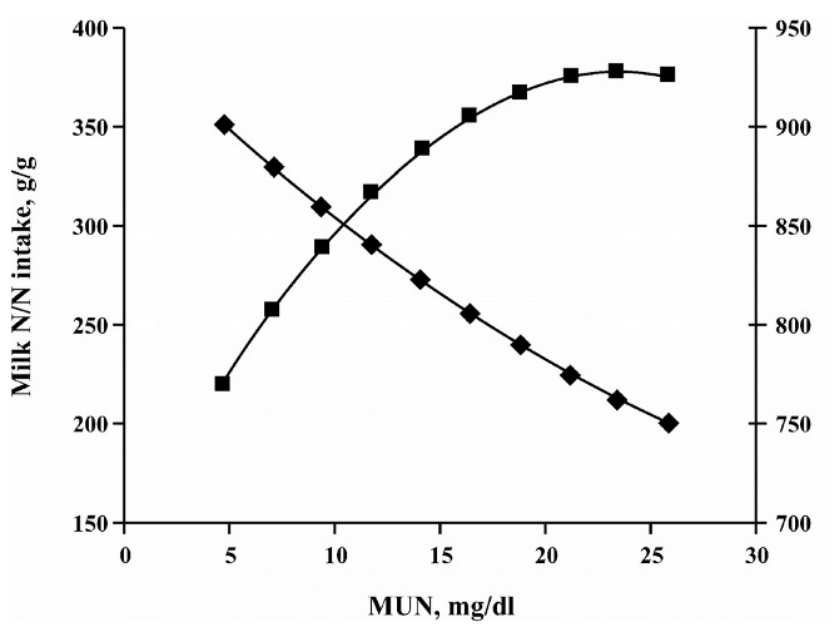

Figure 2. Association between the efficiency of dietary $\mathrm{N}$ for milk protein production $\left[\bullet ; \mathrm{y}=0.0049( \pm 0.00198) \mathrm{x}^{2}-10.3( \pm 1.15) \mathrm{x}+\right.$ $\left.397( \pm 8.6), \mathrm{R}^{2}=0.914, \mathrm{RMSE}=8.7\right]$ and milk protein yield $[\mathbf{\square} ; \mathrm{y}=$ $-0.021( \pm 0.0001) \mathrm{x}^{2}+20.9( \pm 5.69) \mathrm{x}+681( \pm 44.6), \mathrm{R}^{2}=0.833, \mathrm{RMSE}=$ $41.8]$ with MUN based on data derived from protein supplementation studies $(\mathrm{n}=188)$.

respect to environmental $\mathrm{N}$ emissions or reproductive performance).

Measurements of MUN appeared to provide an accurate prediction of urinary $\mathrm{N}$ excretion (Table 6), consistent with previous suggestions (Jonker et al., 1998; Kauffman and St-Pierre, 2001; Kohn et al., 2002). Prediction of the efficiency of $\mathrm{N}$ utilization and urinary $\mathrm{N}$ excretion based on both MUN and milk yield was associated with RMSE of $19.3 \mathrm{~g} / \mathrm{kg} \mathrm{N}$ and $29 \mathrm{~g} / \mathrm{d}$, respectively. Use of mixed effects models improved the $\mathrm{R}^{2}$ and lowered the RMSE of these relationships, but both the intercept and coefficients of the models were relatively unchanged when fixed models were used, suggesting that the prediction may be sufficiently robust to be applied in practice. Furthermore, these equations suggest that changes in urinary $\mathrm{N}$ output in response to dietary changes can be predicted very accurately (Table 6), particularly when protein supplements are fed. Prediction based on MUN alone indicated that urinary $\mathrm{N}$ excretion increased $13.4 \mathrm{~g} / \mathrm{d}$ per unit $(\mathrm{mg} / \mathrm{dL})$ increase in MUN. Corresponding equations reported by Jonker et al. (1998) and Kauffman and St-Pierre (2001) provide somewhat different slopes (12.2 and 17.2, respectively) and assume an intercept of zero. The model of Kauffman and St-Pierre (2001) provides comparable estimates to the prediction equation derived in this evaluation for MUN values of about $12 \mathrm{mg} / \mathrm{dL}$, but further increases in MUN could potentially overestimate urinary N excretion due to the assumption of a zero intercept (Figure 3). Kohn et al. (2002) suggested that live weight should also be included into the prediction of urinary $\mathrm{N}$ excre-

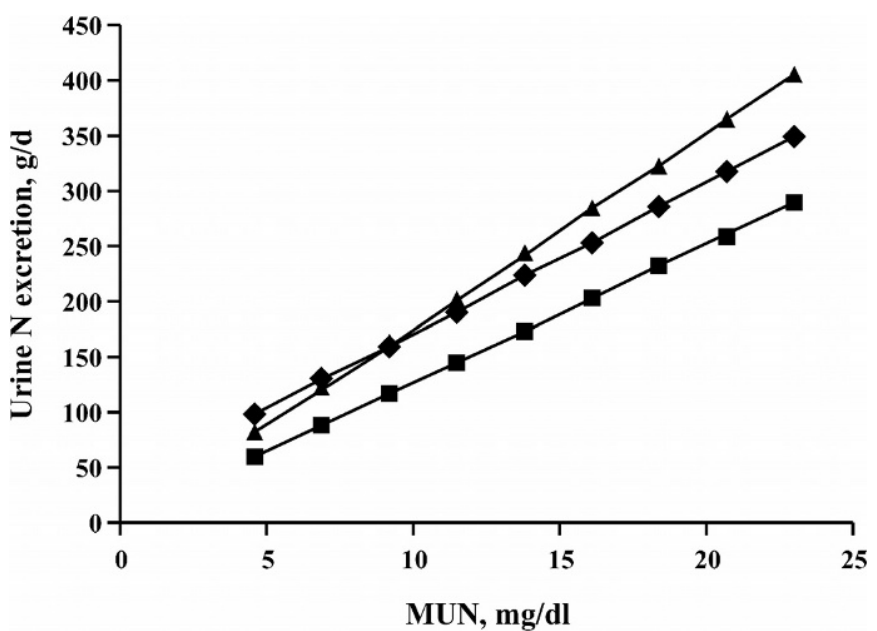

Figure 3. Comparison of the predictions of urinary $\mathrm{N}$ excretion based on milk urea nitrogen (MUN) according to ( ) present data,

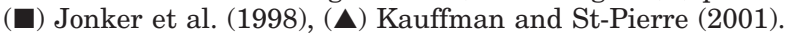

tion that may be in part analogous to the intercept of the relationship derived in this evaluation, whereby the intercept corresponds to the constant effect of live weight. However, live weight in the model of Kohn et al. (2002) appears to be proportional to MUN, not additional as suggested in this study.

Alternatively, urinary $\mathrm{N}$ excretion can be predicted from MUN secretion. Overall, errors in the prediction were numerically similar for MUNS compared with MUN. However, MUNS provided a more accurate prediction when diet composition was manipulated by changes in the level or CP content of concentrate supplements. Predictions of urinary $\mathrm{N}$ excretion could be improved yet further if reliable measurements of dietary $\mathrm{CP}$ content are available. This relationship clearly indicates that urinary $\mathrm{N}$ excretion is primarily governed by dietary CP content. However, the significant contribution of MUNS in the prediction of urinary $\mathrm{N}$ excretion is indicative of the importance of protein quality on both the efficiency of $\mathrm{N}$ utilization for milk protein synthesis and magnitude of $\mathrm{N}$ losses in urine.

\section{CONCLUSIONS}

Dietary concentrations of $\mathrm{CP}$ and $\mathrm{PBV}$ were the main nutritional factors influencing MUN. Associations with MUN were not improved by expressing dietary protein as a function of energy. Nitrogen losses arising from the rumen or liberated during tissue AA catabolism had similar effects on urea secretion in milk. Concentrations of MUN in milk provided a reliable estimate of dietary CP content, whereas MUN or MUNS provided 
an accurate prediction of urinary $\mathrm{N}$ excretion. On the basis of this evaluation, measurement of MUN concentration or secretion can be used to monitor environmental $\mathrm{N}$ emissions associated with milk production.

\section{REFERENCES}

Ahvenjärvi, S., A. Vanhatalo, and P. Huhtanen. 2002. Supplementing barley or rapeseed meal to dairy cows fed grass-red clover silage: I. Rumen degradability and microbial flow. J. Anim. Sci. 80:2176-2187.

Ahvenjärvi, S., A. Vanhatalo, P. Huhtanen, and T. Varvikko. 1999. Effects of supplementation of a grass silage and barley diet with urea, rapeseed meal, and heat-moisture treated rapeseed cake on milk production and omasal digesta flow in lactating dairy cows. Acta Agric. Scand. Sect. A Anim. Sci. 49:179-189.

Annison, E. F. 1983. Metabolite utilization by the ruminant mammary gland. Pages 399-439 in Biochemistry of Lactation, Elsevier Science Publishers B.V., Amsterdam, The Netherlands.

Broderick, G. A., and M. K. Clayton. 1997. A statistical evaluation of animal and nutritional factors influencing concentrations of milk urea nitrogen. J. Dairy Sci. 80:2964-2971.

Carlsson, J., and B. Pehrson. 1994. The influence of the dietary balance between energy and protein on milk urea concentration. Experimental trials assessed by two different protein evaluation systems. Acta Vet. Scand. 35:193-205.

Castillo, A. R., E. Kebreab, D. E. Beever, and J. A. France. 2000. A review of efficiency of nitrogen utilisation in lactating dairy cows and its relationship with environmental pollution. J. Anim. Feed Sci. 9:1-32.

De Peters, E. J., and J. D. Ferguson. 1992. Nonprotein nitrogen and protein distribution in the milk of cows. J. Dairy Sci. 75:3192-3209.

Frank, B., and C. Swensson. 2002. Relationship between content of crude protein in rations for dairy cows and milk yield, concentration of urea in milk and ammonia emissions. J. Dairy Sci. 85:1829-1838.

Godden, S. M., K. D. Lissemore, D. F. Kelton, J. H. Lumsden, K. E. Leslie, and J. S. Walton. 2000. Analytic validation of an infrared milk urea assay and effects of sample acquisition factors on milk urea results. J. Dairy Sci. 83:435-442.

Gustafsson, A. H., and J. Carlsson. 1993. Effects of silage quality, protein evaluation systems, and milk urea content on milk yield and reproduction in dairy cows. Livest. Prod. Sci. 37:91-105.

Hof, G., M. D. Vervoorn, P. J. Lenaers, and S. Tamminga. 1997. Milk urea nitrogen as a tool to monitor protein nutrition of dairy cows. J. Dairy. Sci. 80:3333-3340.

Huhtanen, P. 1998. Supply of nutrients and productive responses in dairy cows given diets based on restrictively fermented silage. Agric. Food Sci. Finl. 7:219-250.

Huhtanen, P., H. Miettinen, and V. Toivonen. 1997. Effects of silage fermentation and postruminal casein supplementation in lactating dairy cows. 1. Diet digestion and milk production. J. Sci. Food Agric. 74:450-458.

Jonker J. S., R. A. Kohn, and R. A. Erdman. 1998. Using milk urea nitrogen to predict nitrogen excretion and utilization efficiency in lactating dairy cows. J. Dairy Sci. 81:2681-2692.

Jonker, J. S., R. A. Kohn, and J. High. 2002. Use of milk urea nitrogen to improve dairy cow diets. J. Dairy Sci. 85:939-946.

Kauffman, A. J., and N. R. St-Pierre. 2001. The relationship of milk urea nitrogen to urine nitrogen excretion in Holstein and Jersey cows. J. Dairy Sci. 84:2284-2294.

Khalili, H., and P. Huhtanen. 2002. Effect of casein infusion in the rumen, duodenum, or both sites on factors affecting forage intake and performance of dairy cows fed red clover-grass silage. J. Dairy Sci. 85:909-918.

Kirchgessner, M., M. Kreuzer, and D. A. Roth-Maier. 1986. Milk urea and protein content to diagnose energy and protein malnutrition of dairy cows. Arch. Anim. Nutr. 36:192-197.
Kohn, R. A., K. F. Kalscheur, and E. Russek-Cohen. 2002. Evaluation of models to estimate urinary nitrogen and expected milk urea nitrogen. J. Dairy Sci. 85:227-233.

Littell, R. C., G. A. Milliken, W. W. Stroup, R. D. Wolfinger. 1996. SAS System for Mixed Models. SAS Inst. Inc., Cary, NC.

McCullough, H. 1967. The determination of ammonia in whole blood by a direct calorimetric method. Clin. Chim. Acta 17:297-304.

Nousiainen, J., M. Rinne, M. Hellämäki, and P. Huhtanen. 2003. Prediction of the digestibility of the primary growth of grass silages harvested at different stages of maturity from chemical composition and pepsin cellulase solubility. Anim. Feed Sci. Technol. 103:97-111.

Oltner, R., and H. Wiktorsson. 1983. Urea concentrations in milk and blood as influenced by feeding various amounts of protein and energy to dairy cows. Livest. Prod. Sci. 10:457-467.

Rajamäki, S., and A. Rauramaa. 1984. The automated determination of urea on milk. Finn. Chem. Lett. 2:47.

Ropstad, E. L., L. Vik-Mo, and A. O. Refsdal. 1989. Levels of milk urea, plasma constituents, and rumen liquid ammonia in relation to the feeding of dairy cows during early lactation. Acta Vet. Scand. 30:199-208.

Roseler, D. K., J. D. Ferguson, C. J. Sniffen, and J. Herrema. 1993. Dietary protein degradability effects on plasma and milk urea nitrogen and milk nonprotein nitrogen in Holstein cows. J. Dairy. Sci. 76:525-534.

Schepers, A. J., and R. G. M. Meijer. 1998. Evaluation of the utilization of dietary nitrogen by dairy cows based on urea concetration in milk. J. Dairy Sci. 81:579-584.

Shingfield, K. J., S. Jaakkola, and P. Huhtanen. 2001. Effects of level of nitrogen fertilizer application and various nitrogenous supplements on milk production and nitrogen utilization of dairy cows given grass silage-based diets. Anim. Sci. 73:541-554.

Shingfield, K. J., M. Jokela, K. Kaustell, P. Huhtanen, and J. Nousiainen. 1999. Association between protein feeding and reproductive efficiency in the dairy cow: specific emphasis on protein feeding in Finland. Agric. Food Sci. Finl. 8:365-392.

Shingfield, K. J., A. Vanhatalo, and P. Huhtanen. 2003. Comparison of heat-treated rapeseed expeller and solvent-extracted soyabean meal as protein supplements for dairy cows fed grass silagebased diets. Anim. Sci. 77:305-317.

St-Pierre, N. R. 2001. Integrating quantitative findings from multiple studies using mixed model methodology. J. Dairy Sci. 84:741-755.

Tilley, J. M. A., and R. A. Terry. 1963. A two-stage technique for in vitro digestion of forage crops. J. Br. Grassl. Soc. 18:104-111.

Tuori, M., K. Kuoppala, J. Valaja, E. Aimonen, E. Saarisalo, and P. Huhtanen. 2002. Rehutaulukot ja ruokintasuositukset 2002 [web document]. Published 28.6.2002, [refereed 28.3.2003]. Web access at: http://www.agronet.fi/rehutaulukot/.

Vanhatalo, A., T. Varvikko, and P. Huhtanen. 2003. Effects of casein and glucose on responses of cows fed diets based on restrictively fermented silage. J. Dairy Sci. 86:3260-3270.

Van Keulen, J., and B. A. Young. 1977. Acid insoluble ash as a natural marker for digestibility studies. J. Anim. Sci. 44:282287.

\section{APPENDIX 1}

This list of publications describes data used to evaluate the effect of dietary and animal factors on milk urea nitrogen. Numbers in parenthesis indicate the number of mean treatment values derived from each citation.

Bertilsson J., R. J. Dewhurst, and M. Tuori. 2002. Effects of legume silages on feed intake, milk production, and nitrogen efficiency. Landbauforschung Voelkenrode, SH 234:39-45. (20).

Heikkilä, T. 1997. Kevät-ja syyssadon sekä valkuais- ja väkirehutason vaikutus maidontuotannossa [The effect of grass silage har- 
vest (primary vs. regrowth) and concentrate supplementation level on milk production]. Pages 183-186 in Proc. of Kotieläintieteen päivät 1997, Maaseutukeskusten Liiton julkaisuja 914. (8).

Heikkilä, T., and P. Huhtanen. 1995. Effects of physical treatment of barley and rapeseed meal in dairy cows given grass silagebased diets. Agric. Food Sci. Finl. 5:399-412. (6).

Heikkilä, T., S. Jaakkola, and P. Huhtanen. 2000. Effect of sodium fertilization of cocksfoot leys on milk production. Pages 157-159 in Grassland Science in Europe 5, Proc. of the 18th General Meeting of the European Grassland Federation Aalborg, Denmark 22-25 May 2000. (15).

Heikkilä, T., S. Jaakkola, R. Sorunen-Cristian, and T. Mela. 2000. Yellow-flowered lucerne-grass silage in milk production. Pages 353-355 in Grassland Science in Europe 5, Proc. of the 18th General Meeting of the European Grassland Federation, Aalborg, Denmark, 22-25 May 2000. (2).

Heikkilä, T., and V. Toivonen. 1997. Herne ja rypsirouhe lehmien valkuaisrehuna säilörehuruokinnalla [Pea and rapeseed meal as protein supplements for dairy cows fed grass silage based diets]. Pages 187-190 in Proc. of Kotieläintieteen päivät 1997, Maaseutukeskusten Liiton julkaisuja 914. (8).

Heikkilä, T., V. Toivonen, and P. Huhtanen. 1998. Effects of and interactions between the extent of silage fermentation and protein supplementation in lactating dairy cows. Agric. Food Sci. Finl. 3:329-343. (6)

Heikkilä, T., V. Toivonen, T. Keskinen, P. Parikka, and T. Tupasela. 1999. Effects of two additives and harvesting methods of wilted silage and concentrate level on milk production. Pages 149-150 in Proc. of the XIIth International Silage Conference, July 5-7, 1999, Uppsala, Sweden. (8).

Heikkilä, T., V. Toivonen, and T. Tupasela. 1997. Effect of additives on big bale silage quality and milk production. Page 119 in J. A. M. van Arendonk, Editor-in-Chief, Book of Abstracts of the 48th Annual Meeting of the European Association for Animal Production: Vienna, Austria, 25-28 August 1997. Wageningen, Wageningen Press. (3).

Huhtanen, P. 1993. The effects of concentrate energy source and protein content on milk production in cows given grass silage ad libitum. Grass and Forage Sci. 48:347-355. (4).

Huhtanen, P., S. Jaakkola, and P. Pärssinen. 2001. Ruokonata lypsylehmien rehuna [Tall fescue as a feed for dairy cows]. Pages 34-38 in (Editors) Niemeläinen, O., M. Topi-Hulmi, and E. Saarisalo, Nurmitutkimusten satoa: tuloksia lannoituksesta, palkokasveista, luomunurmista, laitumista, ruokonadasta. Suomen Nurmiyhdistyksen julkaisu 14. (4).

Huhtanen, P., S. Jaakkola, and E. Saarisalo. 1995. The effects of concentrate energy source on the milk production of dairy cows given a grass silage-based diet. Anim. Sci. 60:31-40. (8).

Huhtanen, P., S. Jaakkola, and J. Kylmänen. 1992. Tärkkelysrankin suojauskäsittelyn ja rypsilisän vaikutus lehmien tuotantoon [The effect of wet distillers grain treatment and protein supplement on milk production]. University of Helsinki, Department of Animal Science, Unpublished. (6)

Huhtanen, P., and H. Miettinen. 1992. Milk production and concentrations of blood metabolites as influenced by the level of wet distiller's solubles in dairy cows receiving grass silage-based diet. Agric. Sci. Finl.1:279-290. (4).

Jaakkola, S., T. Heikkilä, E. Saarisalo, and P. Huhtanen. 2002. Kokoviljasäilörehun soveltuvuus lehmien ruokintaan [Whole crop barley silage for milk production]. Pages 31-43 in Proc. (Editors) E. Saarisalo, and M. Topi-Hulmi, Rehuvaihtoehtoja nautakarjatiloille: seminaari Jokioisilla 29.4.2002, Suomen Nurmiyhdistyksen julkaisu 18. (20).

Jaakkola, S., and P. Huhtanen. 1998. Ohrarehun ja rankin käyttö lypsylehmien ruokinnassa [The use of barley fiber and wet distillers grain for dairy cows]. Agrifood Research Finland, Animal Nutrition. Unpublished. (8).

Jaakkola, S., and E. Joki-Tokola. 1999. Kokoviljasäilörehun soveltuvuus lypsylehmän ruokintaan [Suitability of whole crop silage for dairy cows]. Page E54 in Mitä Suomi syö-ja millä hinnalla? Proc. of Agro-Food '99, Tampere 2.-4.2.1999, Tampere-talo, Helsinki, Agro-Food ry/Agronomiliitto ry. (7)
Jaakkola, S., M. Rinne, T. Heikkilä, V. Toivonen, and P. Huhtanen. 1996. Muurahaishapon annostelutason, rypsirouheen ja propyleeniglykolin vaikutukset maidontuotannossa [The effects of rate of formic acid application for grass silage and supplementation of the rapeseed meal and propylene glycol on milk production]. Pages 213-217 in Proc. Kotieläintieteen päivät 1996, Kotieläintiede 90 vuotta -juhlaseminaari. Maaseutukeskusten Liiton julkaisuja 905. (16)

Jaakkola, S., M. Rinne, K. Huuskonen, V. Vesterinen, and P. Huhtanen. 1995. The effect of silage fermentation on the response to protein supplementation in milk production and rumen fermentation in vitro. Page 68 in Proc. of the VII Symposium on Protein Metabolism and Nutrition, 24-27 May 1995, Estacao Zootecnica Nacional, Portugal. (6)

Khalili, H., P. Huhtanen, K. Rinne, and M. Suvitie. 1997. The effects of two levels of concentrates supplying the same amount of protein on silage intake and milk production in cows given two grass silages. Pages 3-4 in Proc. of the XVIII International Grassland Congress, 8-19 June 1997, Winnipeg, Manitoba, Saskatoon, Saskatchewan, Canada, Volume 2, Session 17 Forage Quality, ID NO. 194. (10).

Khalili, H., E. Kuusela, E. Saarisalo, and M. Suvitie. 1999. Use of rapeseed and pea grain protein supplements for organic milk production. Agric. Food Sci. Finl. 8:239-252. (7)

Khalili, H., A. Sairanen, K. Hissa, and P. Huhtanen. 2001. Effects of type and treatment of grain and protein source on dairy cow performance. Anim. Sci. 72:573-584. (8)

Kokkonen, T., M. Tuori, V. Leivonen, and L. Syrjälä-Qvist. 2000. Effect of silage dry matter content and rapeseed meal supplementation on dairy cows. 1. Milk production and feed utilisation. Anim. Feed Sci. Technol. 84:213-228. (4)

Nousiainen, J. I. 2001. [The effects of concentrate energy and protein allocation on the milk production in dairy cows]. In Nousiainen, J. I. Maitotilojen tuotannonohjauksen ja seurannan kehittämisprojekti, Loppuraportti 1.1.1999-31.3.2001, 35 pages. Agrifood Research Finland, North-Savo Research Station. (4).

Rinne, M., S. Jaakkola, M. Järvi, and P. Huhtanen. 1997. Effects of gradual replacement of rapeseed cake with linseed cake in a grass silage-based diet for dairy cows. Agric. Food Sci. Finl. 6:161-172. (4)

Rinne, M., S. Jaakkola, K. Kaustell T. Heikkilä, and P. Huhtanen. 1999. Silages harvested at different stages of grass growth $v$. concentrate foods as energy and protein sources in milk production. Anim. Sci. 69:251-263. (16)

Rinne, M., S. Jaakkola, T. Varvikko, and P. Huhtanen. 1999. Effects of type and amount of rapeseed feed in milk production. Acta Agric. Scand. 49:137-148. (8)

Saarisalo, E., S. Jaakkola, and P. Huhtanen. 2002. Effects of supplementing grass silage with protein on production of primiparous cows in late lactation. Pages 594-595 in Multi-function grasslands: quality forages, animal products, and landscapes, Grassland Science in Europe 7, Proc. of the 19th general meeting of the European Grassland Federation, La Rochelle, France, 2730 May 2002. (8)

Saarisalo, E., S. Jaakkola, E. Skyttä, and P. Huhtanen. 2002. Maitohappobakteeriymppien vaikutus esikuivattujen säilörehujen laatuun ja lypsylehmien maidontuotantoon [The effects of inoculants on the silage quality and milk production]. Pages 71-74 in Proc. of Maataloustieteen Päivät 2002, Kotieläintiede, 9.10.1.2002 Viikki, Helsinki, Maaseutukeskusten Liiton julkaisuja 977. (8).

Saarisalo, E., S. Jaakkola, and R. Sormunen-Cristian. 1997 Sirppimailassäilörehu lypsylehmien ruokinnassa [Yellow-flowered lucerne-grass silage in the feeding of dairy cows]. Pages 175-177 in Proc. of Kotieläintieteen päivät 1997, Maaseutukeskusten Liiton julkaisuja 914. (2)

Sairanen, A. 2000. Lisävalkuaistaso lypsylehmien kannattavassa ruokinnassa [Protein supplementation level and the profitabilty of milk production]. Koetoiminta ja käytäntö 57(1):7 (8).

Sairanen, A., J. I. Nousiainen, and H. Khalili. 1999. Korkean väkirehumäärän vaikutus maitotuotokseen ja tuotannon kannattavuuteen [The effect of high concentrate level on the yield and 
profitability of milk production]. Page P7 in Mitä Suomi syöja millä hinnalla? Proc. of Agro-Food '99, Tampere 2.-4.2.1999, Tampere-talo, Helsinki, Agro-Food ry/Agronomiliitto ry. (10).

Shingfield, K. J., S. Jaakkola, and P. Huhtanen. 2001. Effects of level of nitrogen fertilizer application and various nitrogenous supplements on milk production and nitrogen utilization of dairy cows given grass silage-based diets. Anim. Sci. 73:541-554. (8)

Shingfield, K. J., S. Jaakkola, and P. Huhtanen. 2002. Effect of forage conservation method, concentrate level and propylene glycol on intake, feeding behaviour, and milk production of dairy cows. Anim. Sci. 74:383-397. (16).

Shingfield, K. J., A. Vanhatalo, and P. Huhtanen. 2003. Comparison of heat-treated rapeseed expeller and solvent-extracted soyabean meal as protein supplements for dairy cows fed grass silagebased diets. Anim. Sci. 77:305-317.

Tuori, M. 1992. Rapeseed meal as a supplementary protein for dairy cows, with the emphasis on the NORDIC AAT-PBV feed protein evaluation system. Agric. Sci. Finl. 1:367-439. (18). 